\title{
The Fiction in Non-Fiction Film
}

\section{La ficción en la película de no ficción}

\section{A ficção em filmes de não ficção}

\author{
Carlos Ruiz Carmona \\ Assistant professor \\ Department: Film and Audiovisual, School of Arts \\ (Universidade Católica Portuguesa do Porto) \\ https://orcid.org/0000-0001-7523-634X \\ Portugal
}

Author's statement

The author hereby declares that the current manuscript that they are submitting is original and has not been published previously and it was not submitted for publication elsewhere.

Reception date: 6 September 2018

Review date: 2 April 2019

Published: 1 July 2019

To cite this article: Carmona, C. R. (2019). The Fiction in Non-Fiction Film, Icono 14, 17 (2), 10-31. doi: 10.7195/ri14.v17i2.1338 


\section{Abstract}

Over the past few decades of film theory, significant scholars and acclaimed filmmakers have established that documentary, just like fiction, must resort to ambiguous and subjective rhetorical figures to represent the world. This claim has led some scholars to conclude that documentary as a term referring to itself as being non-fictional might be disregarding its inevitable fictional elements. This argument may suggest that documentary, just like fiction, when representing the historical world fictionalizes reality.

If we accept this claim as true, we need to ask whether terms such as fiction and non-fiction or documentary make sense when discussing the process of representing reality. Does this claim mean that cinema can only fictionalize reality and therefore we should eradicate from this discussion terms such as non-fiction or documentary?

The questions that this paper intends to answer are:

Can the term fiction exist without referring to the term non-fiction or documentary?

What roles do documentary and fiction play in representing the historical world?

Are these terms necessary to communicate and understand the process of representing reality?

This paper has established that fiction and documentary are necessary terms that emerge in cinema narration as a means to mirror human experience's needs to organize, communicate and understand reality.

Key Words: Documentary; Fiction; Narrative; Representing reality; Subjectivity; Narrative comprehension 


\section{Resumen}

En las últimas décadas, la teoría del cine, los principales académicos y aclamados cineastas han establecido que el documental, al igual que la ficción, debe recurrir a figuras retóricas ambiguas y subjetivas para representar el mundo. Esto ha llevado a algunos estudiosos a concluir que el documental como un término que se refiere a sí mismo como no ficticio podría estar pasando por alto sus inevitables elementos ficticios. Esto puede implicar que tanto el documental como la ficción utilizan las mismas estrategias y obtienen los mismos resultados cuando se representa el mundo histórico: ficcionalizar la realidad.

Si aceptamos esta afirmación como verdadera, debemos preguntarnos si términos como ficción, no ficción o documental tienen sentido cuando se trata de discutir y comprender la representación de la realidad. ¿Significa esto que el cine solo puede ficcionalizar la realidad y, por lo tanto, debemos erradicar de esta discusión términos como la no ficción o el documental?

¿Podemos entender o discutir la representación de la realidad sin referimos a esos términos? ¿Puede el término ficción existir de hecho sin referirse al término no ficción o documental?

Las preguntas que este artículo intenta responder son:

¿Qué papeles juegan el documental y la ficción al representar el mundo histórico?

¿Son necesarios estos términos para discutir, comunicar y comprender la representación de la realidad?

Este artículo establece que la ficción y el documental son términos necesarios que emergen en la narrativa cinematográfica como reflejos de la necesidad de la experiencia humana en organizar, comunicar y comprender la realidad del mundo histórico que habitamos.

Palabras clave: Documental; Ficción; Narrativa; Representación de la realidad; Subjetividad; Comprensión narrativa 


\section{Resumo}

Nas últimas décadas, a teoria do cinema, grandes estudiosos e aclamados cineastas estabeleceram que o documentário, assim como a ficção, deve recorrer a figuras retóricas ambíguas e subjetivas para representar o mundo histórico. Isso levou alguns estudiosos a concluir que o documentário, como um termo que se refere a si mesmo como não-ficcional, pode estar desconsiderando os seus inevitáveis elementos ficcionais. Isso pode implicar que tanto o documentário quanto a ficção usam as mesmas estratégias e obtêm os mesmos resultados ao representar o mundo que habitamos: ficcionalizar a realidade.

Se aceitarmos essa alegação como verdadeira, precisamos de questionar se termos como ficção e não-ficção ou documentário fazem sentido no discurso da representação da realidade. Será que isso significa que o cinema pode apenas ficcionalizar a realidade e, portanto, devemos erradicar nesta discussão termos como não-ficção ou documentário?

Podemos entender ou discutir a representação da realidade sem nos referirmos a esses termos? Pode o termo ficção existir de fato sem se referir ao termo não-ficção ou documentário?

As questões que este artigo pretende responder são:

Que papéis desempenham o documentário e a ficção na representação do mundo histórico?

São esses termos necessários para comunicar e entender a representação da realidade?

Este artigo estabeleceu que a ficção e o documentário são termos necessários que emergem na narração do cinema como uma reflexão das necessidades da experiência humana de organizar, comunicar e compreender a realidade.

Palavras chave: Documentário; Ficção; Narrativa; Representando a realidade; Subjetividade; Compreensão narrativa 


\section{Introduction}

From the very birth of cinema, we have established that representing reality involves a number of complex technical choices and creative possibilities. This process means to transform event information from a three-dimensional historical world into a two-dimensional visual format. Essentially a film narrative substitutes our continue and homogeneous perception of the never-ending flow of reality for a series of audio-visual discontinued fragments. This is a very artificial and ambiguous proceeding for each filmmaker can produce a different representation of the same event. The world we represent continually remind us that it can be represented in countless ways.

Given cinema's technical qualities representing a historical event may raise issues regarding the credibility or authenticity of the representation for representing an event is not just a question of what it is "real" but also a question of what it is "ideal." Cinema needs to be technically credible to engage audiences' narrative comprehension. This means, on the one hand, to satisfy certain cultural or social expectations. On the other, it also means to overcome specific technical restrictions. It is for this reason that representing an event it is not just a question of what an event is but also of what the event should appear technically to be on the cinema screen.

From the very beginning, first film theories and major scholars have researched and questioned cinema's creative potential and technical restrictions for representing reality. How cinema represents or has represented the historical world defines one of the most crucial debates amongst the different aesthetic and ideological tendencies: the ambiguous relationship between the cinematographic discourse and reality. Throughout history, filmmakers had been searching and developing new strategies for representing reality. This partly results from filmmakers' dissatisfactions with previous forms of representation like in the case of British Free Cinema, Direct Cinema or Cinéma Vérite in relation to Grierson's narrator-orator documentary doctrine. On the other hand, this also results from the filmmaker's desire and need to discover and create new rhetorical forms that fit their vision and experience of reality. There are no rules, or set of conventions which can de- 
termine the way we represent the world for the possibilities are endless since techniques, forms or strategies vary under the individual filmmaker who applies them. Bill Nichols's (1991) documentary modes confirm that the concept that fits or not to the documentary term is in continuous evolution and in fact, its development depends greatly on the filmmakers' needs to accomplish personal artistic expression. For this reason, different strategies or modes mostly inhabit one another creating new hybrid forms of representation. Conversely, we should also consider that no strategy or principle of narration can guarantee a credible representation. Pedro Costa's, Patricio Guzman's, Roberto Rossellini's, Frederick Wiseman's, Robert Flaherty's, Jose Luis Guerin's or João Canijo's fiction and documentary films breath truthfulness and authenticity, however, it is not their strategies that make their films credible or artistically valuable. It is their creative and technical individual decisions that shape the authenticity and quality of their representations. Nonetheless, whichever strategy filmmakers implement to make their films, the resulting representation of the event is always bound to be personal, biased, manipulative and subjective. Resorting to a specific shot size or recording a particular sound or dialogue implies a personal subjective choice when representing an event. Since we are all individuals, filmmakers can only represent a subjective point-of-view of the world. Thus, cinema is always bound to be highly manipulative and artificial. Film narratives cannot express a tangible objective reality but only a subjective one: the reality of the filmmaker.

For this reason, major scholars when referring to documentary practice, have argued that documentary shares many of the methods and devices used in fiction and cannot be considered as something picked up from the everyday world we inhabit, but rather as something we made-up and created for the screen. They claim that documentary as a term referring to itself as being non-fictional might be disregarding its inevitable fictional elements. The fact is that documentary like fiction must resort to rhetorical figures when representing the world. It is unavoidable, and in doing so, it must make many technical choices, such as lenses, lighting, composition, camera angles or aperture, which automatically imply a deviation from reality. This process is just as manipulative and subjective as in fiction. This is why some scholars and filmmakers have also argued that documentary when representing the world fictionalizes reality. 


\section{Methodology}

This paper resorts to revising, analyzing and confronting key literature dedicated to the study of documentary, a selected filmography illustrating relevant examples in this discussion, statements from influential documentary filmmakers and scholars and the revision of content chosen from fundamental film theories which have questioned and discussed the role that terms such as fiction and documentary or non-fiction play in representing reality.

\section{Development}

\section{a) The ambiguous nature of representing reality}

Trinh T. Minh-ha's essay, "The Totalizing Quest of Meaning", (Minh-ha, 1993, p90-106) reflects great reservations and skepticism against the socially accepted claim of documentary as a means for representing reality. Since in fact, according to Minh-ha, the word "documentary" unavoidably implies a "truth" claim about the subject which is being represented. Minh-ha argues that documentary, throughout history, has become a privileged medium with the power to capture and represent reality. She argues that it must be questioned on political and philosophical grounds for representation is partly subjected to historical and socio-political contexts and "truth" can be the result of the interest or agenda of institutions or regimes in power.

Rouch, Wiseman, Wexler, Leacock and many other influential filmmakers had defended that their objective in documentary making was to represent the event as close as possible as they experienced it. After long years of making non-fiction films, they all concluded that it was impossible to produce objective representations of reality for each decision is personal and subjective since each filmmaker has a different view on the world. Instead, these highly acclaimed filmmakers often referred to concepts such as "fair" or "just" to justify their decisions when representing a historical event. They have argued that their role in representing the historical world was to be "just." This arguably means to respect the individuality 
and identity of the characters and events they represented in their films. Nowadays, these terms and concerns continue to be used and referred by contemporary filmmakers when discussing their artistic treatment of reality. This is the case of Filipa César's, Salomé Lamas'. João Salaviza's, João Pedro Rodrigues' and João Rui Guerra da Mata's amongst many other internationally acclaimed filmmakers ${ }^{1}$. However, "fair" and "just" are very ambiguous terms and as subjective as the choices involved in film-making since each filmmaker has their guidelines for respecting the "other." There are no clear references or parameters for representing the world with "justice" since it depends on the subjective opinion and judgment of the filmmaker ${ }^{2}$. Thus, terms such as "fair," "honest" or "just," seem much more questionable and ambiguous, if not impossible objectives to achieve in filmmaking.

We should also consider that if a documentary can be partly the result of the politics or values of a culture, then, so can be the filmmaker's point of view of the world, and therefore the choices involved in representing it. Roland Barthes (Barthes, 1982), in the Empire of Signs, when reflecting about his writings of Japan, he argued that, when writing, he was unable to step aside from his Westerner's point of view. He stated that the experience of being a foreigner always conditioned his writing of Japan. That point of view was always present. This means that he could not undo the presence of Western culture on his views of the world. This is why he argued that his writings of Japan could only be a reflection on the experience rather than on the "truth" of the content of his texts. This is also why Trinh Minh-ha (Minh-ha, 1982) declares in her film Reassemblage (1982) that she wants to speak "nearby" instead of "about" Africa. This statement directs our attention not only towards how we represent the world but also at the content that we select from the world to represent it.

Subjectivity in representing reality begins with acknowledging the fact that our choices and views of the world are inevitably conditioned by the culture we inhabit. We are educated to "think" and to "see" from a perspective according to our own culture and life experience. We cannot undo or disregard who we are as cultural-beings for it is part of who we are as individuals. This social, political and cultural context shapes up to a certain extent our views and knowledge of the world and therefore, our subjective choices in the act of representing it. This 
means that the same world we represent conditions the way we experience it and the options involved in representing it.

The fact is that documentary, from its very birth, had to resort to ambiguous and subjective rhetorical figures to represent the world just like fiction. For this reason, fiction and documentary have inhabited one another from the very moment the Lumière brothers gave birth to their invention. They have used and shared rhetorical figures and sometimes exploited each other domains. This is why sometimes, fiction films had also been referred to as documentaries like in the case of Flaherty's Moana (1926), Alexander Dovzhenko's Earth (1930) or most Italian Neorealist films. Then again, some documentaries had also been "mistaken" for fiction films like in the case of Mercedes Álvarez's El Cielo Gira (2004) or Errol Morris's The Thin Blue Line (1988).

In the case of El Cielo Gira, Mercedes Álvarez (Lisbondocs, 2005), on her film's preview at the International Documentary Film Festival of Lisbon in 2005, received several congratulations from the public regarding the "realistic and authentic performances of her social actors." Some members of the audience assumed that her film was fiction and that the characters in her film were actors. However, they were not. They were "real" people. However, Álvarez's technical and creative treatment shaped the narrative content in a "fictional" manner "misleading" some spectators to believe that they were watching fiction instead of a documentary.

Conversely, The Thin Blue Line (1988), a documentary which dramatically re-enacts the crime scene and investigation of a police officer's murder in Dallas, was rejected by the 0scars for the Best Documentary category in 1989 because it was considered to be fictional due to its scripted content. The selection jury interpreted the dramatized and performed scenes as fiction. Errol Morris, through visual re-enacting, presents different visual representations in the narrative of the events in accordance with several witnesses' testimonies. As a whole, these scripted scenes represent a visual "investigation" of the evidence which led to convict the wrong person for murder. The film subsequently played a crucial role in confirming the innocence of the convicted man and in condemning the real criminal. However, these visually enacted situations were, at the time, considered to be fictional by an expert jury. 
In the last few years, due to the development of new technologies, initially with video and recently with digital technology, there has been an outburst of new forms for exploiting a sense of documentary authenticity. Highly popular docu-soaps such as Cops (1989), Survivor (1997), Big Brother (2000), Supernanny (2005), The Real Housewives (2005), Master Chef (2010), Duck Dynasty(2012), What if (2018), Nailed it! (2018) or Making it (2018), brought a new edge to the concept of reality representation. These programs combine dramatic reconstruction, authoritative professional commentary, eye witness testimony and an observational filming strategy. Their narratives are presented like drama series using the already popular and established fictional "soap opera" television format.

Conversely, the commercial success of fiction films such as Blair Witch Project (1999), and more recently, Paranormal Activity (2007), REC (2007) Cloverfiled (2008) and Paranormal Activity 2 (2010), has been based on achieving a new sense of realism in their narratives, by combining documentary conventions with the use of camcorder technology. Furthermore, filmmakers have also taken advantage of various internet channels for promoting their films by providing storyline background information and creating expectations amongst audiences. In the case of Blair Witch Project the market strategy was not based on claiming to be a documentary but on the following underlying premise of the film: "in October 1994, three student filmmakers disappeared in the woods near Burkittsville, Maryland, while shooting a documentary. A year later their footage was found".

In the last few years the effect caused by out-of-focus images, shaky camera movements and pixelated poor quality images, have come to convince audiences of the authenticity of what they see by creating a new sense of film realism. They have set new standards for the representation of reality blurring even further the invisible imaginary line between fiction and non-fiction.

The fact is that both fiction and documentary are equally suitable to represent reality for they are both capable of revealing "truths" about the world we inhabit. Frequently, they exploit each other domains to satisfy the filmmaker's individual needs for artistic self-expression, and they share the same subjective and manipulative methods and strategies to represent reality. Therefore, we should ask 
whether it is possible or not to draw an imaginary line separating documentary and fiction practice? Is it possible in fact to differentiate one from the other with regard to representing reality?

\section{b) The creative treatment of reality}

According to Brian Winston (Winston, 2008), the word "documentary" as an adjective appeared in the English language in 1802. Originally, we can trace it back to the year 1450 as Documentum (lesson), and later to the year 1772 as "document," meaning something written which provides information or evidence. Nowadays, we still refer to the word "document" as evidence. Photography from the very beginning also adopted the status of evidence, and according to Winston, documentary inherited this status as a source of its ideological power in representing the world. As early as 1914 Edward S. Curtis used the terms "documentary material" and "documentary works" to define non-fiction moving images. However, it was John Grierson, in 1926, the first to use the term "documentary" in the English language when referring to Flaherty's fiction film Moana (1926). In the '30s, the term appeared in the English language to specify the content of non-fiction cinema, and in that sense, it was used to differentiate documentary contents from fictional ones. Probably the most famous definition of documentary is that of Grierson's: "creative treatment of actuality." Grierson's definition automatically implies that documentary is not the "truth" for in assuming that a documentary result from a "creative treatment" inevitably undermines the traditional documentary claim of inspiring believe or authenticity. Conversely, Grierson's definition can equally apply to fiction films since fiction can also be considered a "creative treatment of actuality" when representing re-enacted historical or factual events.

Some scholars such as Michael Renov, Llorenç Soler, Arthur Schlesinger, Michael Chanan or Javier Rioyo have claimed that documentary makes use of form and technique in the same way as fiction. Therefore, the choices involved in making documentaries are just as manipulative and subjective as fiction. For this reason, they have argued that documentary is fiction constructed from the elements extracted from everyday reality. Christian Metz (Metz, 1991, p6.), on his essay “0n the Impression of Reality in Cinema", came to strengthen this view by claiming, 
that the spectator, when watching a film, is absorbed by an impression of a reality as if "it is happening now" instead of assuming that in fact, it is a reality that "has already been", and therefore a past reality. The portion of reality presented in the film, according to Metz, belongs to another time which is not the time of watching the film. The event only existed in front of the camera at the time of filming, but it ceased its existence just after the camera recorded it. Thus, according to Metz, cinema presents us with an illusion of the real existence of a past event. What cinema shows us is not reality anymore. It is just an impression of reality presented in the form of a narrative. This is why cinema is an art of fiction and narration for in creating the illusion of reality the movie spectator is absorbed not by an impression of "it has already been there" but rather by a sense of "there it is".

Several documentary filmmakers such as Frederick Wiseman, Haskell Wexler, Albert Maysless, Errol Morris or William Klein have indirectly supported Metz's views by arguing that the subjectivity involved in film making up to a certain extent fictionalize their work. For instance, they have claimed that just selecting a section of a character's dialogue or action to be inserted in a particular time of the narrative is a highly subjective process. A process that cannot guarantee the "truth" of the event but only present a personal point of view. This process transforms the original raw material into a form of fiction. This is why it may not come as a surprise when Wiseman in 1974 referred to his films not as Observational documentaries but as "reality fictions." According to Thomas Benson (2002), Wiseman has used this term at times to illustrate the unavoidable constructive nature of documentary making. At other times Wiseman used this term to defend that his films do not reflect an accurate reality but rather his experience of that reality. ${ }^{3}$

These arguments seem to imply that only non-subjective and manipulative films which do not transform reality can qualify as documentary or non-fiction. From this perspective, everything should be regarded as fiction since manipulation and subjectivity in film making as we have established is entirely unavoidable. Representing a tangible objective reality is not possible in cinema. If this is the case then no longer there is a need for the term non-fiction or documentary. However, why do we need to make use of this term? Is it possible for filmmakers and 
audiences to represent or discuss reality without referring to fiction and non-fiction? The fact is that fiction and documentary are necessary terms to understand and explain reality and denying the existence of one unavoidably also implies eradicating the existence of the other. It is not a question of establishing whether non-fiction is subjective, manipulative or not. It is a question of understanding what role does this term play in representing and communicating reality.

\section{c) The role of fiction and documentary in representing reality}

Spectators view fiction and documentary with reference to a different set of expectations and conventions. Fiction and documentary are terms commonly used by public and professionals alike to identify, discuss, criticize and differentiate content and form in film making. This distinction exists in the very cultural and historical context where films are made and viewed. Noël Carroll (1996) argues that we classify non-fiction films concerning their knowledge claims. Therefore, through classifying narrative content audiences identify or differentiate what is fiction or documentary and producers, distributors or directors make claims about their films' content and technical treatment. A spectator, generally, would not go to see a movie without knowing how it has been classified and therefore without establishing whether it is documentary or fiction.

Furthermore, this classification does not only depend on the producer, distributor or exhibitor for this would mean that they would be deciding what content should be regarded as documentary or fiction. And they do not. They merely provide information according to a set of pre-established codes and conventions, so their films appear identified by the audience as one or the other. It is these pre-established codes and conventions that cues spectators to have a specific position for judging the film content. Therefore, that which the film claims to be will condition significantly how audiences position themselves for undertaking narrative comprehension. For instance, it is considerably different for an audience to regard narrative content about War World II as fiction or a documentary. Regardless of technique and treatment viewers will receive fiction or documentary content about the same subject differently. From this perspective, we can argue that it is society who ultimately judges the narrative content and its artistic treatment. 
Therefore, establishing what can be regarded as fiction or documentary seems to be more of a social and cultural phenomenon.

We can argue that both documentary and fiction make claims about reality, but their relationship with the historical world is substantially different. For instance, Saving Private Ryan (1998) presents a horrifying, shocking and "realistic" account of the Normandy Landings in World War II. Witnesses to that tragic event may corroborate the powerful authenticity of its representation. However, an interview with a survivor, with no special effects, revealing his authentic personal experience of the event, predisposes audiences with a completely different perspective regarding the film content. The survivor's account and experience did happen in the historical world we live in. He may refer to friends that died during the event. He will never see them again. They ceased to exist. Families lost their sons forever. His testimony describes a personal experience that cannot be undone for he did survive the horrifying experience of war. There is no fiction narrative that can substitute that. The fiction narrative draws inspiration from that source to recreate the survivor's real tragic experience.

Spielberg's film might be much more poignant and illustrative that the interviewer's speech in depicting the event. However, the audience knows that it is fiction. People in Spielberg's film did not die. They pretended to die during the act of filming. They performed a character's role which bears no direct relation to the event. However, much research was involved in the creation of Saving Private Ryan the film was the product of the director's and other artists' imagination. Spielberg's film does not offer or indicate a direct reflection of a past reality but the survivor's testimony does through his own life experience, and the audience recognizes that through relating his testimony to his past reality.

This does not mean that fiction films cannot reveal inner "truths" about the world. Fiction and documentary are equally suited to represent and make claims about reality. Documentary and fiction are first of all cinema, meaning that they use the same rhetorical means to represent reality. In some cases, fiction can be more appropriate or accurate for uncovering hidden "truths" like might be the case of Errol Morris' The Thin Blue Line. Morris re-enacted several sequences to 
illustrate how each scene can be equally "truthful" or "untruthful" when depicting past events. These enacted scenes present a perspective about the murder event which he could not have achieved otherwise. Errol Morris, through re-enacting the murder of Dallas police officer Robert Wood, "investigates" what could or not had happened at the time of the murder.

Tongues Untied (1989) by Marlon Riggs uses also enacted scenes to illustrate the problematic personal issues involving black gay identity. Thus, certain concrete aspects of reality are amplified by imagined ones and therefore by addressing the audience emotionally and expressively rather than factually. In Tongues Untied we are invited to experience what it is like to be a black male and gay, attesting to the complexities of racial and sexual relation within gay subculture.

Therefore, resorting to enacting scenes were crucial to satisfying the narrative intentions of these filmmakers. Morris' film had to use enacting scenes to uncover "truths" about past events. The fiction elements in the narrative serve as an effective strategy to investigate the past. The strength of the film lies in fact on the use of enacting. The same applies to Riggs' film. Tongues Untied sets out to make us understand what it feels like to be black and gay in a specific community. Enacting seems particularly well suited to communicate that emotional dimension. However, much enacting was used in their films; they remain documentaries and not fiction. These narratives do not fictionalize reality for enacting means to communicate and explore real-life experience. The scripted scenes serve as evidence of a past reality, the reality of the real-life experience of the characters in their films.

Therefore, it is not the strategy or the subjective nature of filmmaking that turns documentary into fiction. This is why fiction films sometimes have been "mistaken" for documentaries and vice versa. Since narrative's authenticity relies on the filmmaker's technical and creative treatment and not on the strategy itself or whether it is fiction or documentary.

Fiction and non-fiction are equally suitable to document the world, but they fulfill different roles in representing reality. It is not a question of claiming "truths" or being "fair" or attempting to be "objective." These are all extremely ambiguous 
concepts that we cannot achieve in practice even though filmmakers should be inspired and committed to achieving them. Fiction and documentary are terms that serve the purpose of understanding and organizing reality representation in cinema narration. From this perspective, these terms mirror human experience since we all need to know and differentiate in reality what it is real from what it is imagined. We all need to distinguish fact from fiction in real life and in cinema. This is why fiction and documentary serve the purpose of organizing, communicating and understanding the experience of reality into an audio-visual narrative form. Documentary or non-fiction will always refer to that which we know or regard as real in the historical world we inhabit. Therefore, that which exists independently of how we represent it or how we experience it. While fiction will refer to that which we regard as imagined or created by our imagination. Therefore, that which does not exist independently of our own experience or existence.

A documentary, since it is inevitably linked to our experience, predisposes us to a different approach with relation to its claims about the world that is familiar to us. This is why fiction films, when arguing about the historical world, only need to be plausible or believable to engage audiences' attention. Fiction bares no great responsibilities about their claims for they are "fiction." Documentaries must inspire belief and be credible since they speak of, from or about "others" that live in our reality: institutions, cultures or individuals alike. How their subjects appear represented, through cinema's technical qualities, may, therefore, raise ethical, political, social and cultural issues and provoke important debates about the responsibilities of the authors and the events represented.

\section{Conclusion}

First film theories had established cinema as an art form. A technical and creative medium which can be used for satisfying filmmakers' personal needs for artistic self-expression or the political agenda of an institution or a regime in power. Essentially cinema when representing the world replaces our continuous and homogeneous perception of the flow of reality for a limited number of discontinued audio-visual fragments. This technical process involves transforming a three-dimensional experience into a two-dimensional audio-visual representation. 
This is why we can argue that reality when represented it becomes something else. It is another time and another space, and so it becomes another reality in the form of images and sounds. It is a different reality for the world continues to exist independently of how cinema represents it. A character from a film, in the historical world, will grow old and will die eventually.

Conversely, in the film narrative, they will remain visually the same forever "condemned" for all eternity to repeat the same dialogues or actions. Thus, the film narrative content, physically, becomes another reality from that which it represents. Even though cinema does offer evidence of the existence of a past reality the narrative object as such is something else. An object constituted by colour, light, and sound which represents an argument or point of view about a subject. This means that cinema is also part of the same historical world it represents. The narrative film exists within the same time and space frame of the historical world it represents.

It is for this reason that that fiction and non-fiction are necessary terms for audiences and filmmakers to understand, organize, communicate and explain reality and experience. Denying the existence of one of these terms eradicates the possibility of the existence of the other. This also may imply to deny the existence of reality itself or the possibility to understand it and explain it.

First and foremost, both fiction or non-fiction are essential terms for audiences or filmmakers alike to organize and process narrative content and experience. How can a filmmaker, for instance, organize a narrative without knowing, establishing or differentiating one from the other? Conversely, audiences also position narrative comprehension with regard to what narrative claims to be: fiction, non-fiction or a hybrid form of narration. This is why terms such as fiction and non-fiction play different roles in relation to representing reality since spectators regard them with a different set of expectations and conventions. Fiction and documentary are terms commonly used by public and professionals alike to identify, discuss, criticize and differentiate content and form in film making.

For this reason, we can argue that it is society who ultimately judges the narrative content and its artistic treatment. This is why we can argue that fiction and non-fiction 
are mandatory and necessary terms in film narration and narrative comprehension. It is not a question of choice, opinion or argument. It is mandatory for this distinction exists in the very cultural and historical context where films are made and viewed.

We should also consider that we organize and process human experience by identifying and differentiating that which is real from that which is imagined or not real. This is essential for processing human experience since human beings cannot survive without being able to differentiate one from the other. At the same time, we need to take into account that human experience is the main source to inspire film narration. It is through human experience that we communicate and process reality. This is why we may agree that documentaries and fictions are both the result of human experience and from this perspective representing reality implies precisely representing human experience.

We have already established that cinema can never represent a tangible objective reality since all the choices involved in filmmaking are highly subjective and manipulative. This means that all cinematographic discourse is always bound to be ambiguous. However, we should also ask if a human being can experience a tangible objective reality? The fact is that human experience is unique and as biased, manipulative or subjective as fiction or documentary. Therefore, if we cannot experience an objective reality how a filmmaker can represent one? This is also why we can argue that the same world we represent conditions the way we represent it. The way human beings experience reality condition the way filmmakers can represent it. Therefore, if human experience is bound to be subjective so it must be representing reality.

For this reason, we may argue that the terms fiction and documentary emerge in cinema narration to organize and understand reality. It is not a question of claiming the "truth, being "just" or "objective." It is a question of making reality understood in cinema narration as we experience it in the historical world. Therefore, fiction and documentary play different roles regarding representing reality even though they may inhabit one another and exploit each other domains. They satisfy different needs in understanding, organizing and communicating how reality appears represented in cinema. 
The same way human beings need to distinguish fact from fiction in the historical world audiences and filmmakers need to establish what is fiction or non-fiction in narrative forms. This is why we may argue that fiction and documentary serve the purpose of organizing and understanding the experience of reality into an audio-visual narrative form. Documentary or non-fiction will always refer to that which we understand, identify or regard as real in the historical world we inhabit. Therefore, that which exists independently of how we represent it or how we experience it. While fiction will refer to that which we regard as imagined or created by our imagination. Therefore, that which does not exist independently of our own experience or existence.

It is for this reason that we cannot discuss representing reality without recurring to these terms: fiction and non-fiction or documentary. Eradicating one implies the non-existence of the other and the impossibility to understand, communicate or represent reality itself. These terms represent an essential medium to understand and discuss reality and human experience. Fiction and documentary should be regarded and viewed as necessary terms that emerge in cinema narration as a means to mirror human experience's needs to organize, understand and communicate reality.

\section{Bibliographic references}

Álvarez, M. (2005). El Cielo Gira. 2004 at the International Documentary Festival of Lisbon. LisbonDocs. Portugal, 2005

Barthes, R. (1982). Empire of Signs. Translated by Richard Howard. New York: Hill and Wang.

Benson, W. and Anderson, C. (2002). Reality Fictions. The Films of Frederick Wiseman. Carbondale and Edwardsville: Southern Illinois University Press.

Carroll, N. (1996). Theorizing the Moving Image. New York: Cambridge University Press.

Chanan, M. (2003). The Documentary in the Revolution. Cuban Cinema. Minneapolis: University of Minnesota Press.

Cunningham, M. (2005). The Art of Documentary. Ten Conversations with Leading Directors, Cinematographers, Editors and Producers. New York: New Riders Press. 
Jacobs, L. (1979). The Documentary Tradition. New York: W. W. Norton and Company. Klein, W. (2001). Masterclass. Odisseia das Imagens, International Festival of Documentary and New Media. Porto. Portugal.

Leacock, R. interviewed by Shivas, Mark in Cousins, Mark and MacDonald, Kevin (Ed). Imagining Reality, The Faber Book of Documentary, London: Faber and Faber Limited, p. 254-257

Metz, C. (1991). "On the Impression of Reality in Cinema" in Film Language. A Semiotics of the Cinema. Translated by Michael Taylor. Chicago: University of Chicago Press, p.6

Minh-ha's. T. (1993). "The Totalizing Quest of Meaning" in Renov, Michael (Ed). Theorizing Documentary. New York and London: Routledge, p.90-106.

Morris, E. (2005). "Revealing Unexpected Realities" in Cunningham, Megan. The Art of the Documentary: Ten Conversations with Leading Directors, Cinematographers, Editors, and Producers. Berkeley: New Riders Press, p. 50, $51,57,58$

Nichols, B. (1991). Representing Reality: Issues and Concepts in Documentary. Bloomington: Indiana University Press.

Nichols, B. (2001). Introduction to Documentary. Bloomington: Indiana University Press.

Pennebaker, D.A; Hegedus, C. (2005). "Capturing Character. A conversation with Haskell Wexler" in Cunningham, Megan. The Art of the Documentary: Ten Conversations with Leading Directors, Cinematographers, and Producers. New York: New Riders Press, p. 88, 89.

Plantinga, C. R. (1997). Rhetoric and Representation in Nonfiction Film. London: Cambridge University Press.

Renov, M. (1993). Introduction: "The Truth About Non-Fiction." in Renov, Michael (ed.). Theorizing Documentary. New York and London: Routledge, p. 3, 7, 11 Rioyo, J. (2001). "Masterclass. A Mentira da Verdade". Odisseia nas imagens, International Festival of Documentary and New Media. Porto Portugal.

Rouch, J. (1964) interviewed by G.Roy-Leven in Cousins, Mark and MacDonald, Kevin (Ed). Imagining Reality, The Faber Book of Documentary. London: Faber and Faber Limited, 1996, p. 264,265

Schlesinger, A. (1979). "The Fiction of Fact - and the Fact of Fiction" in Jacobs, Lewis. The Documentary Tradition. New York: W.W. Norton \& Company, p.383, 385. 
Soler, L. (2001). "Masterclass, From Homo Sapiens to Homo Zapiens". Odisseia das Imagens. International Festival of Documentary and New Media. Porto, Portugal.

Steve, T. (1996). "Whatever happened to the Social Documentary?" in Cousins, Mark and MacDonald, Kevin (Ed). Imagining Reality, The Faber Book of Documentary. London: Faber and Faber Limited, p. 419-423

The Maysless B. (1964) interviewed by Blue, James. Source: Film Comment. Autumn 1964, Vol. 2, No. in Cousins, Mark and MacDonald, Kevin (Ed). Imagining Reality, The Faber Book of Documentary. London: Faber and Faber Limited, 1996, p. 258-264

Winston, B. (2008). Claiming the Real II. Documentary: Grierson and Beyond. Palgrave Macmillan.

Wiseman, F. (2006) in Doc's Kingdom, 13-18 June of 2006. International Seminar on Documentary Film. Municipal Auditorium Serpa. Portugal. Close Readings. 16th June $16.00 \mathrm{p}: \mathrm{m}$. Analytical approach of his recent work, from excerpts provided by the author.

\section{Filmography}

Álvarez, M. (2004). El Cielo Gira.

Balagueró, J and Plaza, P. (2007). REC.

Riggs, M. (1989). Tongues Untied.

Minh-ha, T. (1983). Reassemblage: From the Firelight to the Screen.

Morris, E. (1988).The Thin Blue Line.

Peli, 0. (2007). Paranormal Activity.

Reeves, M. (2008). Cloverfiled.

Sanchez, E. and Myrick, D. (1999). Blair Witch Project.

Spielberg, S. (1998). Saving Private Ryan.

Williams, Todd. (2010). Paranormal Activity 2.

Wintonick, P. (1999). Cinema Vérité: Defining the Moment. 


\section{Notas}

[1] Porto Summer School on Cinematic Arts. School of Arts. The Catholic University of Portugal. Porto. Portugal. June 18-23, 2018.

[2] Frederick Wiseman: "it would be presumptuous for me or anyone else to say that a particular claim is true. As you said, is a version of the truth. It is your truth. That's why the French cinéma vérité [cinema verite] is ridiculously pompous. "...... "In addition, there is a strong sense of obligation, so the film is a fair account of what I saw, trying to be fair to those who allowed me into their lives." Wiseman, Frederick interviewed by Markun, Paulo. Programa Roda Viva, Television program transmitted in Cultural Television, issued in April 2001 on the occasion of Frederick Wiseman's Retrospective at the 6th Edition of the International Documentary Film Festival, It is All True. Sao Paolo. Brazil)

[3] Frederick Wiseman: "For example, my documentaries have fictional aspects to them. For example, the structure. You could argue hypothetically that instead of showing ... For example, Belfast lasts 4 hours. But I had 115 hours of film. To know something about Belfast, you should see the 115 hours of film, but people would be totally bored. In order not to make the movie boring, one must find structure. The job of giving a shape to a story is like in a fiction film, because I have to build a dramatic structure that works "... ..." There are elements in the editing of a documentary that is similar to writing a fiction film. In particular the construction of its formal aspects. In terms of themes, how to read, for example, metaphors or abstract ideas are in terms of image and relationship with images, like. “ Wiseman, Frederick interviewed by Markun, Paulo. Programa Roda Viva, Television program transmitted inCultural Television, issued in April 2001 on the occasion of Frederick Wiseman's Retrospective at the 6th Edition of the International Documentary Film Festival It's All True. Sao Paolo. Brazil)

\section{(). (1) \&}

Esta obra está bajo una licencia de Creative Commons Reconocimiento-NoComercial 4.0 Internacional. 